\title{
Death at Sea: Passenger and Crew Mortality on Cruise Ships
}

\author{
Travis W. Heggie ${ }^{1 *}$, Tracey Burton-Heggie ${ }^{1}$ \\ ${ }^{1}$ Bowling Green State University, School of Human Movement, Sport and Leisure Studies, Bowling Green, $\mathrm{OH}$ \\ 43403, USA
}

Corresponding Author: Travis W. Heggie, PhD, FFTM RCPS (Glasg), Associate Professor, Bowling Green State University, School of Human Movement, Sport and Leisure Studies, 112 Eppler South, Bowling Green, OH 43403, USA. Tel: +1-8083132168, Fax: +1-4193720383, Email: theggie@bgsu.edu

Received September 9, 2020; Accepted November 18, 2020; Online Published November 22, 2020

\begin{abstract}
Introduction: This study reports the global occurrence of passenger and crew mortality on cruise ships. To date, no comprehensive study of passenger and crew mortality has been published.

Methods: All data on passenger and crew mortality between 2000 and 2019 were obtained from 78 ocean and river cruise lines registered globally and analyzed by their age, gender, nationality, cruise line, and recorded cause of death.

Results: There were 623 reported deaths. Out of all deaths, $89 \%$ were passenger deaths and $11 \%$ were crew deaths. United States residents accounted for $61 \%$ of passenger deaths and crew from India (18\%) and the Philippines (17\%) recorded the highest crew deaths. Falls overboard or onto lower decks (23\%), suicide, murder, and a terror attack (19\%), unspecified natural causes $(18 \%)$, and cardiac incidents $(16 \%)$ were the primary causes of passenger deaths. Suicide and murder $(29 \%)$ and falls overboard or from height $(24 \%)$ were the primary cause of crew member deaths. The most passenger deaths occurred on Carnival Cruise Lines (29\%), Royal Caribbean Cruises $(12 \%)$, and Norwegian Cruise Line (10\%). The highest crew member deaths occurred on Carnival Cruise Line (19\%) and Royal Caribbean Cruises (19\%).

Conclusion: Falls overboard or onto lower decks, cardiac incidents, and suicides are the leading cause of passenger deaths. Suicide and murder and falls are the leading cause of death for crew members. Travel health advisories targeting US citizen passengers and crew members from India and the Philippines are warranted. The addition of mental health care to ship infirmaries is also suggested.

Keywords: Travel, Cruise Ships, Mortality, Falls, Myocardial Infarction, Suicide
\end{abstract}

Citation: Heggie TW, Burton-Heggie T. Death at sea: passenger and crew mortality on cruise ships. Int J Travel Med Glob Health. 2020;8(4):146-151. doi:10.34172/ijtmgh.2020.25.

\section{Introduction}

Travelling by sea is one of the earliest known forms of transportation. ${ }^{1,2}$ From ancient times to the present, people have traveled by sea for reasons such as trade, conquest, and leisure. ${ }^{2,3}$ Over the past few decades, travel by sea for the purpose of cruise tourism has become exceptionally popular. ${ }^{4}$ For example, from 2009-2018 the annual number of individuals boarding cruise ships increased from 17.8 million to 28.2 million passengers. ${ }^{5}$ Since then, the cruise ship industry has been recognized as the fastest-growing segment of the global travel and tourism industry. ${ }^{6,7}$

Given the increasing popularity of cruise tourism and the expansion of the industry into new markets, cruise industry researchers have raised concerns about passenger and crew safety. ${ }^{8}$ For instance, as the industry continues to expand it is likely more passengers and crew will be exposed to life-threatening injury and illness. ${ }^{9,10}$ The existing research literature has done well to identify traveler's diarrhea and respiratory infections as frequent illnesses incurred on cruise ships and cardiovascular incidents as a frequent issue leading to the death of elderly passengers. ${ }^{911-16}$ Additional studies have raised concern about the occurrence of varicella and hepatitis E outbreaks on cruise ships. ${ }^{17,18}$ However, while these studies have provided valuable data to the Vessel Sanitation Program and the ILI (Influenza-like illness) surveillance mechanism operated by the US Centers for Disease Control and Prevention, they are still limited in number and scope. ${ }^{12}$ For example, only a few known studies have investigated the mortality of cruise ship passengers and none have investigated the global occurrence of passenger and crew mortality on cruise ships. ${ }^{8,16,19,20}$

Deaths on cruise ships often receive considerable media

Copyright $(0) 2020$ The Author(s). This is an open-access article distributed under the terms of the Creative Commons Attribution License (http:// creativecommons.org/licenses/by/4.0), which permits unrestricted use, distribution, and reproduction in any medium, provided the original work is properly cited. 
attention. In turn, this attention threatens to have a negative economic impact on the cruise industry and the travel destinations dependent on the industry. Knowing the distribution and factors contributing to deaths on cruise ships can be helpful in the management of ship infirmaries and planning for medical emergencies. It is also key to developing preventive initiatives. In order to address the limited knowledge about cruise ship mortality, this study aims to examine the global incidence and patterns of passenger and crew mortality.

\section{Methods}

A retrospective analysis was conducted using data collected by the International Cruise Ship Wave Network. This network is a global research initiative that collects all fatal incident reports of passenger and crew deaths from 51 registered ocean cruise lines and all 27 registered river cruise lines. For the purpose of this study, only data from leisure-based cruises were utilized. Cruise ships were defined as large passenger ships used for ocean or river voyages in which the voyage itself, the onboard amenities, and the different ports of call form the passenger experience. Data from smaller utility-based ferries with the primary purpose of transporting passengers, cargo, and vehicles from one destination to another were excluded from this study.

All fatal incident reports involving passenger and crew deaths from January 1, 2000 to December 31, 2019 were reviewed and coded in an IBM SPSS statistical spreadsheet (v. 22.0). Each incident was first classified as an onshore or onthe-boat incident. The date of the incident, the gender, age, the nationality of each victim, and the name of the reporting cruise ship were coded and entered into the database. The primary cause of death and any contributing factor or comorbidity as determined by a medical examiner, coroner, or equivalent authority were entered for each fatal incident. Cross-tabulations and descriptive statistics were performed to summarize the data. No living subject ethical approval was required for the completion of this study.

\section{Results}

Between January 1, 2000 and December 31, 2019 there were 623 reported deaths on cruise ships globally. Five hundred and fifty-seven (89\%) of these deaths were classified as passenger deaths and $66(11 \%)$ deaths involved crew members. The number of passenger deaths ranged from a low of three in 2001 to a high of 75 deaths in 2015 and the number of crew deaths ranged from zero reported in 2000-2003 to 10 reported deaths in 2019 (Table 1).

The number of deaths reported by nationality is displayed in Table 2. Out of the 623 total deaths, the majority were from the United States (61\%) followed by the United Kingdom (7\%), Canada (4\%), Australia (3\%), and Italy (3\%). When broken down by passenger and crew deaths, passengers from the United States (66\%) again had the highest number of deaths followed by the United Kingdom (7\%), Canada (4\%), Australia (3\%), and Italy (2\%). In contrast, crew members from India (18\%) and the Philippines (17\%) recorded the highest number of crew deaths. The highest
Table 1. Total Reported Deaths on Cruise Ships, 2001-2019

\begin{tabular}{|c|c|c|}
\hline Year & Passenger & Crew \\
\hline 2019 & 27 & 10 \\
\hline 2018 & 38 & 5 \\
\hline 2017 & 46 & 6 \\
\hline 2016 & 44 & 4 \\
\hline 2015 & 75 & 5 \\
\hline 2014 & 20 & 6 \\
\hline 2013 & 20 & 5 \\
\hline 2012 & 27 & 1 \\
\hline 2011 & 51 & 6 \\
\hline 2010 & 39 & 4 \\
\hline 2009 & 37 & 3 \\
\hline 2008 & 25 & 1 \\
\hline 2007 & 33 & 2 \\
\hline 2006 & 33 & 3 \\
\hline 2005 & 16 & 4 \\
\hline 2004 & 10 & 1 \\
\hline 2003 & 4 & 0 \\
\hline 2002 & 4 & 0 \\
\hline 2001 & 3 & 0 \\
\hline 2000 & 5 & 0 \\
\hline Total & 557 & 66 \\
\hline
\end{tabular}

number of passenger deaths (Table 3) were reported from Carnival Cruise Line (29\%), Royal Caribbean Cruises (12\%), Norwegian Cruise Line (10\%), Holland American Line (8\%), and Princess Cruises (8\%). Carnival Cruise Line and Royal Caribbean Cruises both accounted for 19\% of the total crew deaths followed by Norwegian Cruise Line at $14 \%$.

The gender of deceased passengers and crew members was disclosed in $92 \%$ of the fatality reports. Males accounted for $58 \%$ of the passenger deaths and $76 \%$ of crew deaths. The age of the deceased was reported for 564 (93\%) of the total passenger and crew deaths (Table 4 ). The age groups reporting the highest number of passenger deaths were passengers aged 70-79 (18\%), 60-69 (17\%), and 50-59 (15\%). The age groups reporting the highest number of crew deaths were crew members aged 20-29 (50\%) and 30-39 (22\%).

Out of the total passenger deaths, $87 \%$ occurred on board the cruise ship and $13 \%$ occurred while the passengers were in the port and participating in onshore excursions. Injury trauma such as falls into the sea or to lower decks accounted for $23 \%$ of passenger deaths, $19 \%$ were the result of suicide, murder, and a terror attack in Tunisia, 18\% died from unspecified natural causes, $16 \%$ died from cardiac-related incidents, and $5 \%$ died from pre-existing conditions such as late-stage cancer (Table 5). In contrast, suicide and murder accounted for $29 \%$ of crew deaths while falls overboard and falls from height accounted for an additional $24 \%$. Alcohol was identified as a contributing factor in $52 \%$ of the passenger falls but was not identified as a factor in crew falls.

\section{Discussion}

Despite the image of safe all-inclusive vacations projected by the international cruise industry, incidents resulting in the 
Table 2. Reported Passenger Deaths by Nationality, 2001-2019

\begin{tabular}{|c|c|c|c|}
\hline Cruise Line & Passenger & Crew & Total \\
\hline Australia & 18 & 0 & 18 \\
\hline Bahamas & 1 & 0 & 1 \\
\hline Belarus & 1 & 0 & 1 \\
\hline Belgium & 1 & 0 & 1 \\
\hline Bosnia & 0 & 1 & 1 \\
\hline Brazil & 3 & 3 & 6 \\
\hline Bulgaria & 0 & 1 & 1 \\
\hline Canada & 23 & 0 & 23 \\
\hline Chile & 0 & 1 & 1 \\
\hline China & 3 & 0 & 3 \\
\hline Croatia & 0 & 1 & 1 \\
\hline Denmark & 1 & 0 & 1 \\
\hline Finland & 2 & 0 & 2 \\
\hline France & 9 & 0 & 9 \\
\hline Germany & 12 & 1 & 13 \\
\hline India & 3 & 12 & 15 \\
\hline Indonesia & 0 & 4 & 4 \\
\hline Ireland & 3 & 1 & 4 \\
\hline Israel & 2 & 0 & 2 \\
\hline Italy & 13 & 3 & 16 \\
\hline Japan & 3 & 0 & 3 \\
\hline Macedonia & 0 & 1 & 1 \\
\hline Malaysia & 1 & 0 & 1 \\
\hline Mauritius & 0 & 2 & 2 \\
\hline Mexico & 6 & 2 & 8 \\
\hline Peru & 0 & 1 & 1 \\
\hline Philippines & 0 & 11 & 11 \\
\hline Poland & 2 & 0 & 2 \\
\hline Portugal & 1 & 0 & 1 \\
\hline Romania & 0 & 1 & 1 \\
\hline Russia & 6 & 0 & 6 \\
\hline Serbia & 0 & 2 & 2 \\
\hline Singapore & 1 & 0 & 1 \\
\hline Spain & 6 & 0 & 6 \\
\hline Sweden & 2 & 0 & 2 \\
\hline South Africa & 3 & 1 & 4 \\
\hline Taiwan & 1 & 0 & 1 \\
\hline Ukraine & 0 & 1 & 1 \\
\hline United Kingdom & 37 & 5 & 42 \\
\hline United States & 370 & 8 & 378 \\
\hline West Indies & 1 & 0 & 1 \\
\hline Unreported & 22 & 3 & 25 \\
\hline Total & 557 & 66 & 623 \\
\hline
\end{tabular}

death of passengers and crew do occur. The present study is the first to report the global occurrence of passenger and crew deaths on cruise ships and was successful in identifying 623 deaths between 2000 and 2019. It should be emphasized the intent of this study is not to find fault or suggest unsafe conditions exist aboard cruise ships. However, it is difficult to ignore the high number of passenger deaths on Carnival Cruise Line, Royal Caribbean Cruises, Norwegian Cruise Line, Holland America Line, and Princess Cruises. Out of a total of 78 registered cruise lines internationally, these five lines account for almost $70 \%$ of all passenger deaths. Given that Carnival Cruise Line, Royal Caribbean Cruises, and Norwegian Cruises alone control $77 \%$ of the global cruise market, the higher number of deaths reported on these cruise
Table 3. Reported Passenger and Crew Deaths by Cruise Line, 2001-2019

\begin{tabular}{|c|c|c|}
\hline Cruise Line & Passenger Deaths & Crew Deaths \\
\hline Alaskan Dream Cruises & 0 & 1 \\
\hline Carnival Cruise Line & 159 & 13 \\
\hline Celebrity Cruises & 33 & 4 \\
\hline Costa Cruises & 4 & 3 \\
\hline Cunard Line & 9 & 2 \\
\hline Disney Cruise Line & 11 & 1 \\
\hline Dream Cruises & 1 & 0 \\
\hline Fred. Olsen Cruises & 6 & 0 \\
\hline Holland America Line & 45 & 5 \\
\hline Magic 1 Cruises & 1 & 0 \\
\hline MS Serenissima & 0 & 1 \\
\hline MSC Cruises & 35 & 5 \\
\hline National Geographic & 2 & 0 \\
\hline Norwegian Cruise Line & 55 & 9 \\
\hline P\&O Cruises & 14 & 2 \\
\hline Prime Time Travel & 3 & 0 \\
\hline Princess Cruises & 42 & 4 \\
\hline Regent Seven Seas Cruises & 4 & 1 \\
\hline Royal Caribbean Cruises & 66 & 13 \\
\hline Scandinavian World Cruises & 1 & 0 \\
\hline Seabourn Cruises & 11 & 0 \\
\hline Silja Line Cruises & 1 & 0 \\
\hline Silversea Cruises & 3 & 0 \\
\hline Spirit of America Cruises & 1 & 0 \\
\hline Star Cruises & 6 & 0 \\
\hline Tallink \& Silja Line & 2 & 0 \\
\hline TUI Cruises & 1 & 1 \\
\hline Viking Cruises & 2 & 0 \\
\hline Unreported & 39 & 1 \\
\hline Total & 557 & 66 \\
\hline
\end{tabular}

Table 4. Age Group Distribution Reported for Passenger and Crew Deaths, 2001 2019

\begin{tabular}{lcc}
\hline Age Group & Passenger & Crew \\
\hline $90-99$ & 6 & 0 \\
$80-89$ & 49 & 0 \\
$70-79$ & 100 & 1 \\
$60-69$ & 94 & 8 \\
$50-59$ & 83 & 2 \\
$40-49$ & 58 & 7 \\
$30-39$ & 50 & 14 \\
$20-29$ & 56 & 32 \\
$10-19$ & 12 & 0 \\
$0-9$ & 10 & 0 \\
Unreported & 39 & 2 \\
Total & $\mathbf{5 5 7}$ & $\mathbf{6 4}$ \\
\hline
\end{tabular}

lines is likely proportional to the number of passengers they carry.

The predominance of United States citizens accounting for $61 \%$ of all passenger deaths is not surprising given that passengers from North America consistently make up for over $50 \%$ of cruise passengers each year. ${ }^{5}$ Almost all passenger deaths involving US citizens were reported from cruise destinations in the Caribbean, Bahamas, and Bermuda; destinations easily accessible to passengers basing from the United States. Likewise, the prevalence of passengers aged 50- 
Table 5. Cause of death Reported for Passenger and Crew, 2001-2019

\begin{tabular}{|c|c|c|}
\hline Cause of Death & Passenger Deaths & Crew Deaths \\
\hline Anaphylaxis & 1 & 0 \\
\hline Aneurysm & 1 & 1 \\
\hline Asphyxia/choking/smoke inhalation & 11 & 0 \\
\hline Cardiac incident & 89 & 8 \\
\hline Drowning (ship pool) & 9 & 0 \\
\hline \multicolumn{3}{|l|}{ Falls } \\
\hline Fall from height & 21 & 2 \\
\hline Fall overboard & 58 & 14 \\
\hline Fall from bed (rough seas) & 5 & 0 \\
\hline Slip/Fall & 2 & 1 \\
\hline Internal bleeding & 1 & 0 \\
\hline Legionnaires disease & 3 & 0 \\
\hline Meningococcal meningitis & 1 & 0 \\
\hline Multiple organ failure & 1 & 0 \\
\hline \multicolumn{3}{|l|}{ Murder } \\
\hline Head trauma & 2 & 2 \\
\hline Multiple trauma & 3 & 0 \\
\hline Stabbing & 1 & 0 \\
\hline Strangulation & 1 & 0 \\
\hline Thrown overboard & 7 & 4 \\
\hline Myocarditis (viral) & 2 & 0 \\
\hline Natural causes (unspecified) & 98 & 5 \\
\hline Norovirus & 8 & 0 \\
\hline Pneumonia & 10 & 1 \\
\hline \multicolumn{3}{|l|}{ Pre-existing condition } \\
\hline Cancer & 10 & 0 \\
\hline Cirrhosis & 1 & 0 \\
\hline COPD & 1 & 0 \\
\hline GI hemorrhage & 1 & 0 \\
\hline Kidney failure & 2 & 0 \\
\hline Parkinsons disease & 1 & 0 \\
\hline Unspecified & 10 & 1 \\
\hline Pulmonary embolism & 1 & 0 \\
\hline Respiratory complication (TB) & 2 & 1 \\
\hline Septicemia & 3 & 1 \\
\hline Stroke & 8 & 1 \\
\hline \multicolumn{3}{|l|}{ Suicide } \\
\hline Hanging & 2 & 8 \\
\hline Drug overdose & 5 & 0 \\
\hline Jump overboard & 55 & 5 \\
\hline Jump to lower deck & 8 & 0 \\
\hline Toxic gas exposure & 0 & 3 \\
\hline \multicolumn{3}{|l|}{ Trauma } \\
\hline Head trauma & 2 & 0 \\
\hline Crush injury & 2 & 2 \\
\hline \multicolumn{3}{|l|}{ Onshore / Excursion Deaths } \\
\hline All-Terrain vehicle crash & 2 & 0 \\
\hline Bus crash & 15 & 0 \\
\hline Bicycle crash & 1 & 0 \\
\hline Car crash & 4 & 1 \\
\hline Cardiac (hiking) & 1 & 0 \\
\hline \multicolumn{3}{|l|}{ Drowning } \\
\hline Swimming in sea & 12 & 0 \\
\hline Overturned boat & 1 & 0 \\
\hline Dune buggy crash & 2 & 0 \\
\hline Float plane crash & 13 & 2 \\
\hline Motor scooter crash & 2 & 2 \\
\hline Terror attack & 21 & 0 \\
\hline Unreported cause & 33 & 1 \\
\hline Total & 557 & 66 \\
\hline
\end{tabular}

79 accounting for $40 \%$ of passenger deaths is not surprising given the known demographics of cruise passengers. Prior research investigating illnesses and injuries among cruise passengers has consistently identified passengers in the 5079 age demographic as having the highest number of medical incidents. ${ }^{11,13}$

The present study was successful in identifying key trends supported by existing research. For instance, the high number of cardiac incidents supports prior studies that identify cardiovascular emergencies as some of the most common critical incidents leading to death on cruise ships. ${ }^{3,14}$ Additionally, existing research investigating passenger injuries reports that almost one-third of the injuries occur while the passengers are onshore. ${ }^{8}$ Bus crashes, swimming at beaches, and nature-based excursions were identified as common onshore activities leading to passenger injuries. While only $13 \%$ of all passenger deaths in the present study occurred while the passengers were onshore, bus crashes, float plane crashes, and swimming were the most common activities leading to death. The lone terror attack killing 21 passengers during an onshore excursion has not been discussed in existing research but does highlight a growing concern that cruise ships and their passengers are vulnerable targets. ${ }^{21,22}$

Two additional areas of concern identified in this study are the high number of deaths related to falls overboard or onto lower decks and the high number of deaths related to suicide and murder. Slips, trips, and falls are known to be common injury events on cruise ships. ${ }^{8}$ The fact that $15 \%$ of passenger deaths and $26 \%$ of crew member deaths in the present study resulted from falls indicates that falls are also common events leading to death on cruise ships. Moreover, while there were a few cases of elderly passengers falling from bed during rough seas, the majority of the cases for both passengers and crew involved falls overboard and falls to lower decks. Alcohol consumption and passengers climbing up on and sitting on deck railings were common factors contributing to falls. Most modern cruise vessels have man overboard camera systems in place that can capture any fall. However, they are not alarm systems alerting the boat that someone has fallen overboard. Thus, in the absence of a witness to the fall, an individual can be left behind in the water for hours or days until their absence is reported and the camera tapes are reviewed.

Cruise ships are often described as the perfect location for murder given the perceived ease of dumping victims overboard and the lack of any clear law enforcement jurisdiction in international waters. However, cruise ships are not commonly thought of as a gateway for those intending to commit suicide. Suicide is a complex issue and high numbers of suicides among tourist populations and seafarers working on merchant ships have been previously documented. ${ }^{23-25}$ The fact that $13 \%$ percent of passenger deaths and $20 \%$ of crew member deaths in this study can be attributed to suicides identifies a new area of concern for the cruise industry. Jumps overboard were the suicide method of choice in $79 \%$ of passenger suicides and $38 \%$ of crew suicides. Moreover, out of the 70 passenger suicides identified in this study, $14 \%$ were the result of domestic conflict, $14 \%$ were attributed to alcohol and drug addiction, and $13 \%$ were attributed to pre-existing 
health conditions with a terminal diagnosis. This latter finding suggests that some passengers go on cruises with the intent to commit suicide. In contrast, all crew suicides involved employees from less developed countries and were attributed to long-term separation from family and social networks, poor working conditions, and economic stress.

\section{Conclusion}

The purpose of this study was to report on the global distribution and occurrence of deaths on cruise ships. As evidenced by this study, a variety of deaths occur while cruising that impacts both passengers and crew members. With the popularity and growth of the cruise ship industry expected to continue globally, emphasizing saving lives beyond the required lifeboats, life rafts, and life preservers should be expected. This includes continued and improving monitoring for any falls and jumps overboard or to lower decks. The upgrading of medical facilities and medical care on cruise ships is always welcome but given the high number of suicides amongst passengers and crew, the addition of mental health care is warranted. Likewise, given the predominance of the United States citizens in the overall death totals, any travel health advisory and awareness campaign measures intended to help passengers have the safest cruise experience possible should specifically target United States citizens intending to cruise. The same can be done for potential crew members from India and the Philippines. As with any retrospective study, the present study was restricted by the limitations of that study design and a concern for underreporting. However, this should not overlook the uniqueness of the data and documented deaths of the 623 passengers and crew.

\section{Authors' Contributions}

Both authors were responsible for the study conception, data collection, and data interpretation. TWH was responsible for the preparation of the manuscript. Both authors read and approved the final version of the manuscript.

\section{Conflict of Interest Disclosures}

The authors have declared no conflict of interest.

\section{Ethical Approval}

This study did not require ethics committee approval.

\section{Funding/Support}

No funding sources.

\section{Acknowledgements}

The authors wish to express their gratitude to the team and staff of the Cruise Ship Wave Network for their assistance and dedication to data collection.

\section{References}

1. Minooee A, Rickman LS. Infectious diseases on cruise ships. Clin Infect Dis. 1999;29(4):737-743. doi:10.1086/520426.

2. Tatem AJ, Rogers DJ, Hay SI. Global transport networks and infectious disease spread. Adv Parasitol. 2006;62:293-343. doi:10.1016/s0065-308x(05)62009-x.

3. Wheeler RE. Travel health at sea: cruise ship medicine. In:
Research Highlights

\section{What Is Already Known?}

Existing research on cruise ships has primarily focused on illness, infectious disease, and disease outbreaks.

\section{What This Study Adds?}

This study identifies falls overboard or to lower decks, suicides, and cardiac incidents as the leading causes of passenger deaths on cruise ships. Suicides, murder, and falls overboard or to lower decks are the leading cause of death for crew members. United States citizens account for the majority of cruise passenger deaths while crew members from India and the Philippines account for the highest number of crew deaths.

Zuckerman JN, editor. In: Principles and Practice of Travel Medicine. West Sussex: Wiley-Blackwell; 2013. p. 380-393.

4. Ottomann C, Siemers F, Antonic V. Fire on cruise ships-an underestimated risk in travel medicine. Travel Med Infect Dis. 2015;13(6):509-510. doi:10.1016/j.tmaid.2015.10.003.

5. Cruise Lines International Association (CLIA). 2019 Cruise Trends \& Industry Outlook. https://cruising.org/news-and-research/-/ media/CLIA/Research.pdf. Accessed May 23, 2020.

6. Weeden C, Lester JA, Thyne M. Cruise tourism: emerging issues and implications for a maturing industry. J Hosp Tour Manag. 2011;18(1):26-29. doi:10.1375/jhtm.18.1.26.

7. Dwyer L, Douglas N, Livaic Z. Estimating the economic contribution of a cruise ship visit. Tour Mar Environ. 2004;1(1):516. doi:10.3727/154427304774865841.

8. Dahl E. Passenger accidents and injuries reported during 3 years on a cruise ship. Int Marit Health. 2010;61(1):1-8.

9. Pavli A, Maltezou HC, Papadakis A, et al. Respiratory infections and gastrointestinal illness on a cruise ship: a three-year prospective study. Travel Med Infect Dis. 2016;14(4):389-397. doi:10.1016/j. tmaid.2016.05.019.

10. Bansal V, Fortlage D, Lee JG, Hill LL, Potenza B, Coimbra R. Significant injury in cruise ship passengers: a case series. Am J Prev Med. 2007;33(3):219-221. doi:10.1016/j.amepre.2007.05.004.

11. Yamakawa M, Sasai M, Kasai Y, Tsuda T, Suzuki E. Diarrhea and related factors among passengers on world cruises departing from Japan. Travel Med Infect Dis. 2018;23:56-63. doi:10.1016/j. tmaid.2018.01.004.

12. Millman AJ, Kornylo Duong K, Lafond K, Green NM, Lippold SA, Jhung MA. Influenza outbreaks among passengers and crew on two cruise ships: a recent account of preparedness and response to an ever-present challenge. J Travel Med. 2015;22(5):306-311. doi:10.1111/jtm.12215.

13. Peake DE, Gray CL, Ludwig MR, Hill CD. Descriptive epidemiology of injury and illness among cruise ship passengers. Ann Emerg Med. 1999;33(1):67-72. doi:10.1016/s0196-0644(99)70419-1.

14. Novaro GM, Bush HS, Fromkin KR, et al. Cardiovascular emergencies in cruise ship passengers. Am J Cardiol. 2010; 105(2):153-157. doi:10.1016/j.amjcard.2009.09.004.

15. Connolly R, Prendiville R, Cusack D, Flaherty G. Repatriation of human remains following death in international travellers. J Travel Med. 2017;24(2). doi:10.1093/jtm/taw082.

16. Fujita DM, da Silva Nali LH, de Cassia Giraldi R, Figueiredo GM, de Andrade Júnior HF. Brazilian public health policy for cruise ships-a review of morbidity and mortality rates-2009/2015. Int J Travel Med Glob Health. 2017;6(1):11-15. doi:10.15171/ ijtmgh.2018.03.

17. Rice ME, Bannerman M, Marin M, et al. Maritime varicella illness and death reporting, U.S., 2010-2015. Travel Med Infect Dis. 
2018;23:27-33. doi:10.1016/j.tmaid.2018.04.001.

18. Said B, ljaz S, Kafatos G, et al. Hepatitis E outbreak on cruise ship. Emerg Infect Dis. 2009;15(11):1738-1744. doi:10.3201/ eid1511.091094.

19. Dahl E. Passenger mortalities aboard cruise ships. Int Marit Health. 2001;52(1-4):19-23.

20. Bledsoe GH, Brill JD, Zak D, Li G. Injury and illness aboard an Antarctic cruise ship. Wilderness Environ Med. 2007;18(1):36-40. doi:10.1580/06-weme-or-029r.1.

21. Walker CM. Cruise ships: the next terrorism target? Travel Law Quarterly. 2012;2:124-135.
22. Heggie TW. Terrorism and travel medicine: where do we go from here? Travel Med Infect Dis. 2018;22:1-2. doi:10.1016/j. tmaid.2018.03.004.

23. Heggie TW, Heggie TM, Kliewer C. Recreational travel fatalities in US national parks. J Travel Med. 2008;15(6):404-411. doi:10.1111/ j.1708-8305.2008.00235.x.

24. Roberts SE, Jaremin B, Chalasani P, Rodgers SE. Suicides among seafarers in UK merchant shipping, 1919-2005. Occup Med. 2010;60(1):54-61. doi:10.1093/occmed/kqp133.

25. Low A. Seafarers and passengers who disappear without a trace from aboard ships. Int Marit Health. 2006;57(1-4):219-229. 